Génét. Sél. Evol., 1987, 19 (4), 445-458

\title{
Direct and correlated responses to selection for large and small 6-week body weight in mice
}

\author{
Yolanda BAYON, L.F. FUENTE and F. SAN PRIMITIVO \\ Departamento de Producción Animal, Universidad de León, León, Spain
}

\begin{abstract}
Summary
A selection experiment based on individual performance for large $\left(\mathrm{W}^{+}\right)$and small $\left(\mathrm{W}^{-}\right)$ 6-week body weight was conducted for 15 generations in mice. A 3 rd line, C, was maintained as an unselected control. Direct responses measured as deviations from the control line were similar in $\mathrm{W}^{+}(10.63 \mathrm{~g})$ and $\mathrm{W}^{-}(-9.23 \mathrm{~g})$. Realized heritabilities for 6-week weight were $0.27 \pm 0.02$ in $\mathrm{W}^{+}, 0.29 \pm 0.02$ in $\mathrm{W}^{-}$and $0.28 \pm 0.01$ for divergence. Correlated responses for 3-week body weight did not show asymmetry, the corresponding values being $3.42 \mathrm{~g}$ and $-3.81 \mathrm{~g}$ for upward and downward selection, respectively. Realized genetic correlations were $0.96 \pm 0.03$ between 6-week and 3-week weight and $0.50 \pm 0.01$ between 6-week weight and 3-6 week gain. Litter size at 1 st, 2nd and 3rd parity was hardly modified in the upward selection $\left(\mathrm{W}^{+}\right)$, whereas it was considerably reduced in the downward selection $\left(\mathrm{W}^{-}\right)$. Realized genetic correlations estimated from the divergence were $0.21 \pm 0.07$ between 6-week weight and first litter size and $0.29 \pm 0.04$ between 6-week weight and the total number of young born in the first 3 births (TNY-3).
\end{abstract}

Key words : Mice, body weight, selection, litter size.

\begin{abstract}
Résumé
Réponses directe et corrélée à une sélection divergente sur le poids corporel à l'âge de six semaines chez la souris
\end{abstract}

Une expérience de sélection divergente sur le poids individuel à l'âge de 6 semaines a été conduite pendant 15 générations chez la souris (lignée haute: $W^{+}$, lignée basse : $W^{-}$). Une $3^{e}$ lignée non sélectionnée $(\mathrm{C})$ a été maintenue comme témoin. Les réponses directes mesurées en déviations par rapport à la lignée témoin sont similaires dans les lignées $W^{+}(10,63 \mathrm{~g})$ et $\mathrm{W}^{-}$ $(-9,23 \mathrm{~g})$. Les héritabilités réalisées du poids à 6 semaines sont de $0,27 \pm 0,02$ dans la lignée $\mathrm{W}^{+}, 0,29 \pm 0,02$ dans la lignée $\mathrm{W}^{-}$et $0,28 \pm 0,01$ pour la divergence. Les réponses corrélées sur le poids corporel à l'âge de 3 semaines ne présentent pas d'asymétrie, les valeurs correspondantes étant respectivement de $3,42 \mathrm{~g}$ et $-3,81 \mathrm{~g}$ dans les lignées haute et basse. Les corrélations génétiques réalisées sont de $0,96 \pm 0,03$ entre les poids à 6 et 3 semaines d'âge et de $0,50 \pm 0,01$ entre le poids à 6 semaines et le gain 3-6 semaines. La taille de portée à la $1^{\mathrm{re}}, 2^{\mathrm{e}}$ et $3^{\mathrm{e}}$ mise bas est à peine modifiée dans la lignée haute $\left(\mathrm{W}^{+}\right)$, alors qu'elle est considérablement réduite dans la lignée basse $\left(\mathrm{W}^{-}\right)$. Les corrélations génétiques réalisées, estimées à partir de la divergence, sont de $0,21 \pm 0,07$ entre le poids à 6 semaines et la taille de la $1^{\text {re }}$ portée et de $0,29 \pm 0,04$ entre le poids à 6 semaines et le nombre total de jeunes nés lors des 3 premières mises bas (TNY-3).

Mots clés: Souris, poids corporel, sélection, taille de portée. 


\section{Introduction}

Body weight is a trait of considerable importance that has been intensely studied in laboratory animals. Selection for body weight in mice has generally led to a substantial direct response (see reviews by EISEN, 1974 and McCARTHY, 1982). The possibility of improving litter size following selection for increased body weight has been frequently considered. However results are variable : an increase in litter size has been described (EISEN et al., 1973; EISEN, 1978) while in some cases no change became evident (BRADFORd, 1971 ; Barria \& BRADFord, 1981).

A two way selection experiment for large and small 6-week body weight was performed for 15 generations. The objective of this experiment was to evaluate the changes that appear both in weight and reproduction traits following divergent selection for body weight.

\section{Materials and methods}

Mice used in the present experiment were obtained from a randombred population which was divided into 3 lines : $\mathrm{W}^{+}, \mathrm{C}$ and $\mathrm{W}^{-}$. Lines $\mathrm{W}^{+}$and $\mathrm{W}^{-}$were selected on the basis of individual performance for large and small 6-week body weight, respectively. Line $\mathrm{C}$ was maintained as an unselected control. Selection was performed over 15 generations.

The lines were reproduced from 50 mating pairs in each generation for generations 1-8 and 40 mating pairs for generations $9-15$, that change being caused by limitations in the animal house. Males and females were pair-mated randomly at 50-60 days of age with avoidance of full-sib mating. Standardization of litter size to 8 mice was performed at 2 days of age in order to reduce the maternal effect. Selection was practised on first litter progeny. No overlapping of generations occurred.

The following data were recorded:

- individual body weight at 3 and 6 weeks of age ;

- litter size (number of live young born) at 1st, 2nd and 3rd parity ;

- number of fertile matings, measured as the number of females having the litter within 15 days of birth of the first.

Details of the breeding procedures as well as results obtained up to generation 8 have been previously described (Fuente \& SAN Primitivo, 1985).

Realized heritability was calculated as direct response regressed on cumulative selection differential. Realized genetic correlation between 2 traits was calculated using the formula of RutLEDGE et al. (1973) :

$$
\mathrm{r}_{\mathrm{Gr}}=\mathrm{b}_{\mathrm{CR} / \mathrm{R}}\left(\mathrm{h}_{\mathrm{x}} \sigma_{\mathrm{Px}} / \mathrm{h}_{\mathrm{y}} \sigma_{\mathrm{Py}}\right)
$$

where $b_{C R / R}$ is the realized genetic regression of correlated response in trait " $y$ " on direct response in trait $" x$ ». Standard errors of $h^{2}$, and $r_{G r}$ were based on the formulae presented by HiLL (1971). 


\section{Results}

Six week body weights for generations $1-15$ of lines $\mathrm{W}^{+}, \mathrm{C}$ and $\mathrm{W}^{-}$are depicted in figure 1 , the values used for the graphs being the average of male and female means. Standard errors of the means are also depicted for the selected lines.

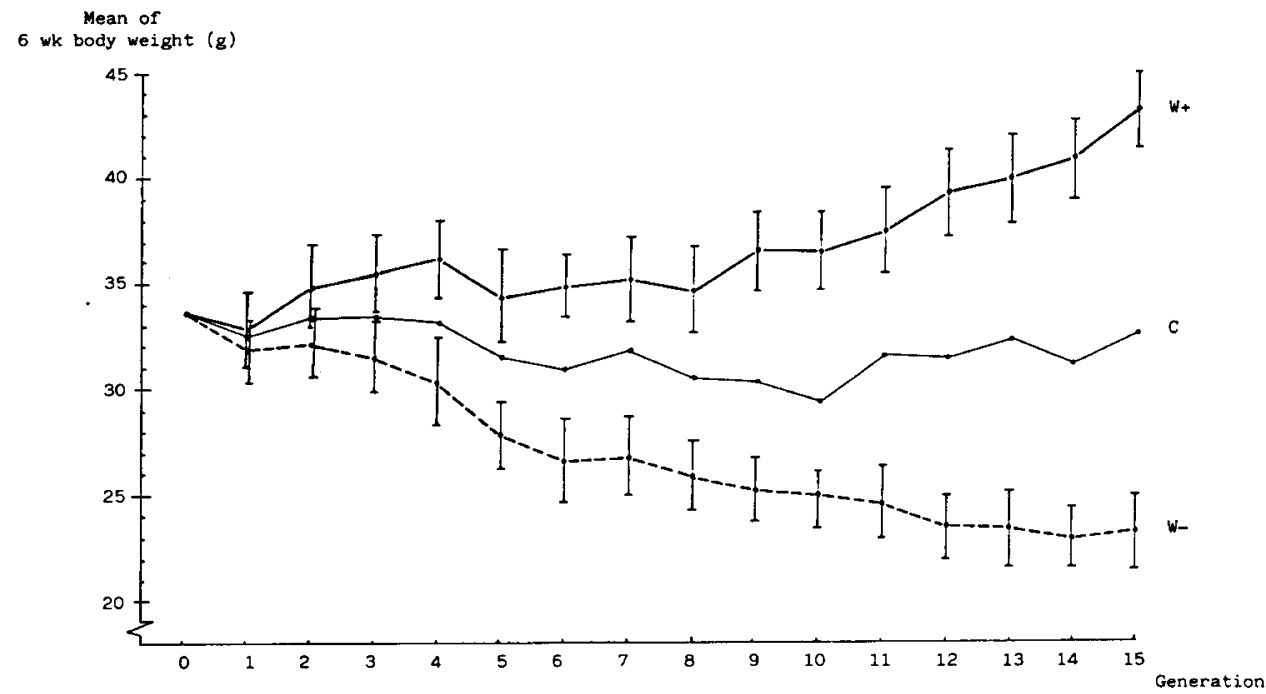

FIG. 1

Means of 6-week body weight in $W^{+}, W^{-}$and $C$ line.

The difference between the $\mathrm{W}^{+}$and $\mathrm{W}^{-}$lines increased gradually and reached its maximum in generation 15. A decline in the selected and control lines was observed possibly due to environmental effects. After 15 generations of selection, 6-week body weight in the line $\mathrm{W}^{+}(43.21 \mathrm{~g})$ nearly doubled that of line $\mathrm{W}^{-}(23.35 \mathrm{~g})$.

The inbreeding coefficient was estimated from genealogical data until generation 13, showing a small increase with generations. Estimates were based on the common ancestors of 5 generations for each individual. The base population was considered generation 0 . After 13 generations of selection the average inbreeding coefficient was 2.83 p. $100,3.63$ p. 100 , and 1.22 p. 100 in the $\mathrm{W}^{+}, \mathrm{W}^{-}$and $\mathrm{C}$ lines. The average increase per generation was 0.22 p. $100,0.28$ p. 100 and 0.09 p. $100 \mathrm{in} \mathrm{W}^{+}, \mathrm{W}^{-}$and $\mathrm{C}$, respectively.

\section{A. Selection differential}

Realized selection differentials (SDr) for upward and downward selection for generations 1-15 are shown in table 1 . SDr per generation were quite constant through all the experiment, the values being higher in $\mathrm{W}^{+}$than in $\mathrm{W}^{-}$. 
TABLE 1

Realized selection differential (SDr) and response $(R)$ of 6-week body weight.

\begin{tabular}{c|c|c|c|c}
\hline \multirow{2}{*}{ Generation } & \multicolumn{2}{|c|}{ Line $W^{+}$} & \multicolumn{2}{c}{ Line $W^{-}$} \\
\cline { 2 - 5 } & SDr & R & SDr & R \\
\hline \multirow{2}{*}{1} & 2.08 & 0.27 & -2.10 & -0.79 \\
2 & 2.11 & 0.97 & -2.07 & -0.75 \\
3 & 2.35 & 0.64 & -2.15 & -0.56 \\
4 & 2.70 & 1.12 & -1.67 & -0.83 \\
5 & 2.45 & -0.17 & -1.75 & -1.25 \\
6 & 1.76 & 1.06 & -1.87 & -0.10 \\
7 & 2.28 & -0.49 & -1.84 & -0.80 \\
8 & 2.20 & 0.70 & -1.45 & 0.37 \\
9 & 2.90 & 1.98 & -2.63 & -0.58 \\
10 & 2.89 & 1.15 & -2.33 & 0.95 \\
11 & 2.58 & -1.17 & -2.39 & -2.50 \\
12 & 2.81 & 1.65 & -2.19 & -1.06 \\
13 & 2.37 & -0.15 & -1.89 & -0.94 \\
14 & 3.05 & 2.20 & -2.27 & 0.63 \\
15 & 2.76 & 0.87 & -1.86 & -1.02 \\
Cumulative & 37.29 & 10.63 & -30.46 & -9.23 \\
\hline \hline
\end{tabular}

Cumulative selection differential was $37.29 \mathrm{~g}$ in $\mathrm{W}^{+}$and $-30.46 \mathrm{~g}$ in $\mathrm{W}^{-}$after 15 generations of selection. The average SDr estimated from divergence was $4.5 \mathrm{~g}$ per generation.

Expected selection differential (SDe) in $\mathrm{W}^{+}(37.53 \mathrm{~g})$ was nearly equal to realized selection differential. On the contrary $\mathrm{SDe}$ in $\mathrm{W}^{-}(-32.53 \mathrm{~g})$ showed a larger value than SDr.

\section{B. Direct response and realized heritability}

Direct responses ( $\mathrm{R}$ ) to selection for 6-week body weight in $\mathrm{W}^{+}$and $\mathrm{W}^{-}$are given in table 1. After 15 generations of selection the cumulative response estimated as deviation from the control line was $10.63 \mathrm{~g}$ for upward selection and $9.23 \mathrm{~g}$ for downward selection. Response calculated from divergence plotted against cumulative selection differential is depicted in figure 2.

Realized heritability was estimated in 2 different periods (generations 1-8 and generations 9-15), the corresponding values being presented in table 2.

Estimates of $\mathrm{h}^{2}$ in $\mathrm{W}^{+}$for generations 9-15 showed an increase in comparison with generations 1-8 (Fuente \& SAN Primitivo, 1985). On the contrary, $h^{2}$ in $W^{-}$declined in the second period relative to the previous generations. However differences did not reach statistical significance. Realized heritability estimated from the divergence for generations 1-15 was $0.28 \pm 0.01$, which did not differ significantly from the values obtained in the separate periods $(0.29 \pm 0.01$ in generations $1-8$ and $0.30 \pm 0.01$ in generations 9-15). 


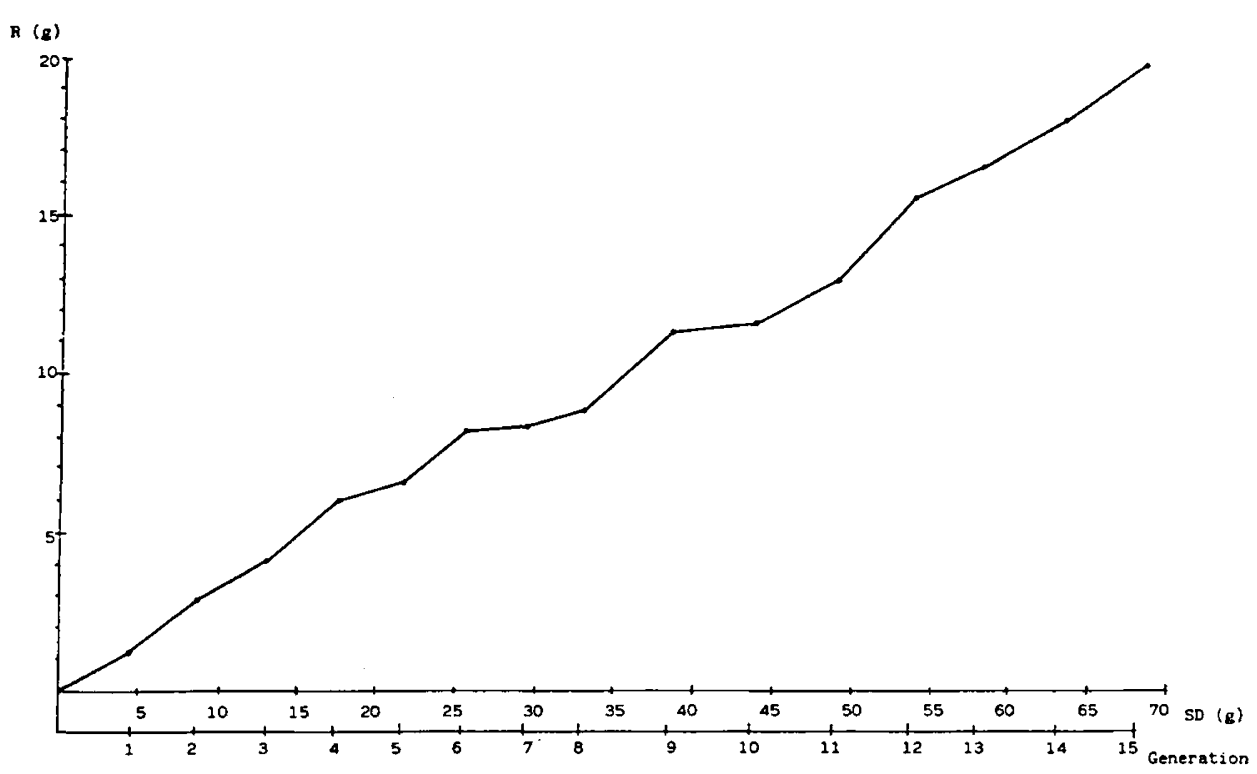

Fig. 2

Response to selection for the divergence $(R)$ plotted against cumulative selection differential $(S D)$.

TABLE 2

Realized heritability for 6-week body weight.

\begin{tabular}{c|c|c|c}
\hline \hline Generations & Line $\mathrm{W}^{+}$ & Line $\mathrm{W}^{-}$ & Divergence \\
\hline $1-8$ & $0.24 \pm 0.03$ & $0.35 \pm 0.03$ & $0.29 \pm 0.01$ \\
$9-15$ & $0.29 \pm 0.04$ & $0.32 \pm 0.04$ & $0.30 \pm 0.02$ \\
$1-15$ & $0.27 \pm 0.02$ & $0.29 \pm 0.02$ & $0.28 \pm 0.01$ \\
\hline
\end{tabular}

C. Correlated responses to selection

\section{Growth traits}

Weaning weight (3-week) as well as 3-6 week gain were modified as a result of selection for 6-week body weight. Partition of 6-week body weight means into the 2 components (3-week weight and 3-6 week gain) for the $\mathrm{W}^{+}, \mathrm{C}$ and $\mathrm{W}^{-}$lines in generation 15 is shown in figure 3 .

At the end of the selection process 3-week body weight means were $17.38 \mathrm{~g}$ and $10.15 \mathrm{~g}$ in the $\mathrm{W}^{+}$and $\mathrm{W}^{-}$lines, respectively. Cumulative responses estimated as deviations from the $\mathrm{C}$ line were $3.42 \mathrm{~g}$ in $\mathrm{W}^{+}$and $-3.81 \mathrm{~g}$ in $\mathrm{W}^{-}$. 

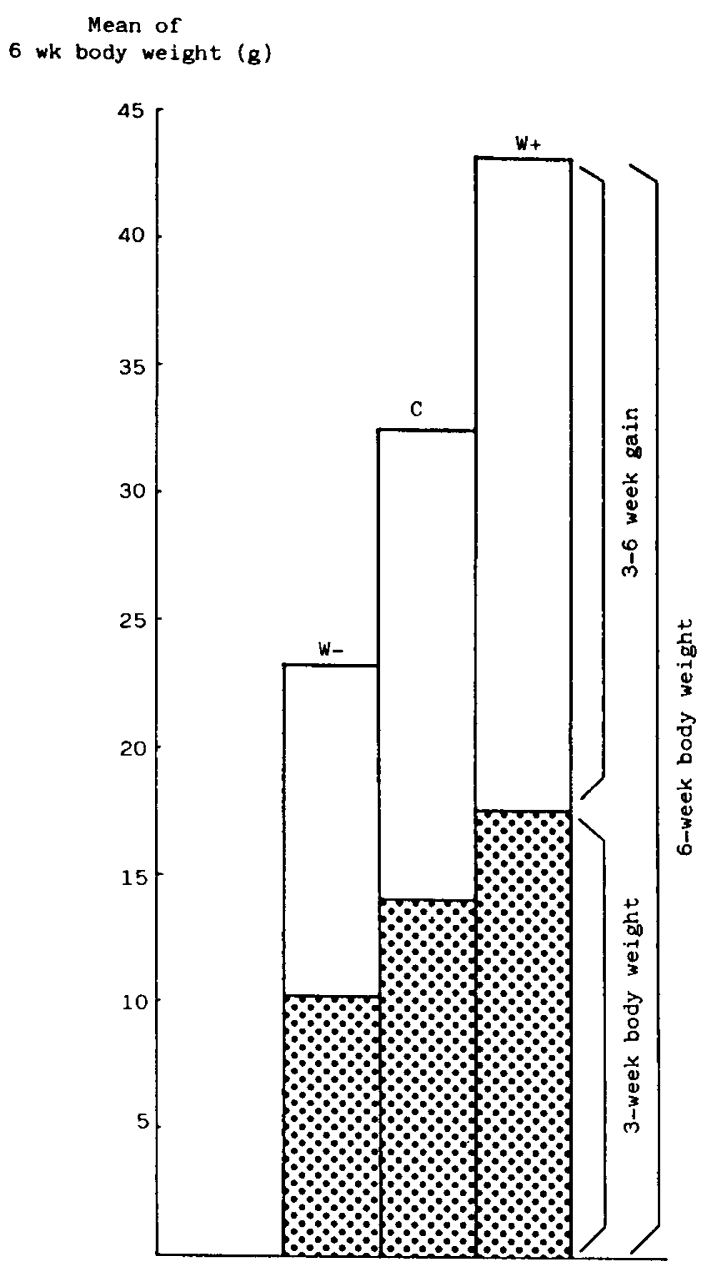

FIG. 3

Partition of 6-week weight means (generation 15) into the 2 components : 3-week weight and 3-6 week gain.

Thus, after 15 generations of selection the magnitude of changes in 3-week weight was similar in the high and low lines, whereas results obtained up to generation 8 (Fuente \& SAN Primitivo, 1985) had shown a larger response in $\mathrm{W}^{-}$than in $\mathrm{W}^{+}$.

Postweaning gain in generation 15 was $25.83 \mathrm{~g}$ in the $\mathrm{W}^{+}$line and $13.20 \mathrm{~g}$ in the $\mathrm{W}^{-}$line. Cumulative response measured as deviation from the control line was higher in $\mathrm{W}^{+}(7.21 \mathrm{~g})$ than in $\mathrm{W}^{-}(-5.42 \mathrm{~g})$.

Realized genetic correlations estimated for the growth traits were high $(0.96 \pm 0.03$ between 6-week and 3-week weight and $0.50 \pm 0.07$ between 6-week weight and 3-6 week gain). 


\section{Reproduction}

Correlated responses in litter size for each parity estimated from the divergence are summarized in table 3. After 15 generations of selection correlated response in the total number of young born in the first 3 births (TNY-3) was 14.85 mice, the corresponding values for each parity being 5.6, 5.23 and 4.48 mice for the 1st, 2 nd and 3 rd litter size, respectively.

TABLE 3

Correlated response in 1st, 2nd and 3rd litter size for the divergence between the $W^{+}$and $W^{-}$lines.

\begin{tabular}{c|c|c|c|c}
\hline \multirow{3}{*}{ Generation } & \multicolumn{4}{|c}{ Litter } \\
\cline { 2 - 5 } & 1st & 2nd & 3rd & TNY-3 * \\
\hline & & 1.43 & 0.47 & 1.67 \\
2 & 0.61 & 0.07 & 0.41 & 2.19 \\
3 & 1.97 & 1.18 & 0.06 & 3.03 \\
4 & 1.73 & 0.76 & 0.98 & 2.81 \\
5 & 1.06 & 1.51 & 2.52 & 3.96 \\
6 & 1.95 & 1.28 & 1.82 & 6.16 \\
7 & 2.12 & 1.14 & 2.55 & 2.86 \\
8 & 2.73 & 1.76 & 0.57 & 2.65 \\
9 & 2.06 & 1.43 & 0.15 & 3.11 \\
10 & 1.77 & 2.84 & 2.24 & 7.98 \\
11 & 2.76 & 3.23 & 1.59 & 9.18 \\
12 & 4.05 & 4.09 & 1.85 & 10.94 \\
13 & 3.72 & 2.57 & 3.85 & 10.14 \\
14 & 3.98 & 4.75 & 3.85 & 13.78 \\
15 & 5.34 & 5.23 & 4.48 & 14.85 \\
\hline
\end{tabular}

* TNY-3 : total number of young born in the first 3 births.

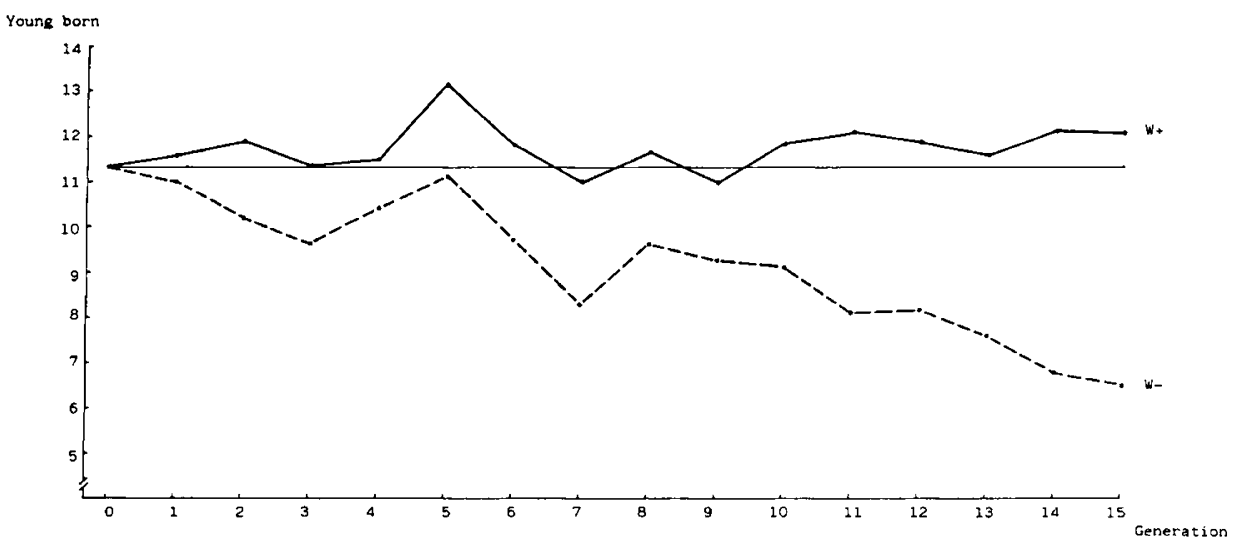

FIG. 4

Means of lst litter size in $W^{+}$and $W^{-}$deviated from the control line. 
The means of the first litter sizes in $\mathrm{W}^{+}$and $\mathrm{W}^{-}$deviated from the control line are graphed for generations 1-15 in figure 4. Changes in 1st litter size following selection for 6-week body weight were much larger in the $\mathrm{W}^{-}$line $\left(-4.85\right.$ mice) than in the $\mathrm{W}^{+}$ line $(0.75$ mice $)$. Actually, changes in $\mathrm{W}^{+}$measured as deviations from the $\mathrm{C}$ line over generations did not reach statistical significance.

The average number of young born in the first 3 births (TNY-3) over generations for the $\mathrm{W}^{+}, \mathrm{C}$ and $\mathrm{W}^{-}$lines are depicted in figure 5. A decline in TNY-3 was observed in the control and the selected lines through all the experiment (as already pointed out for body weight).

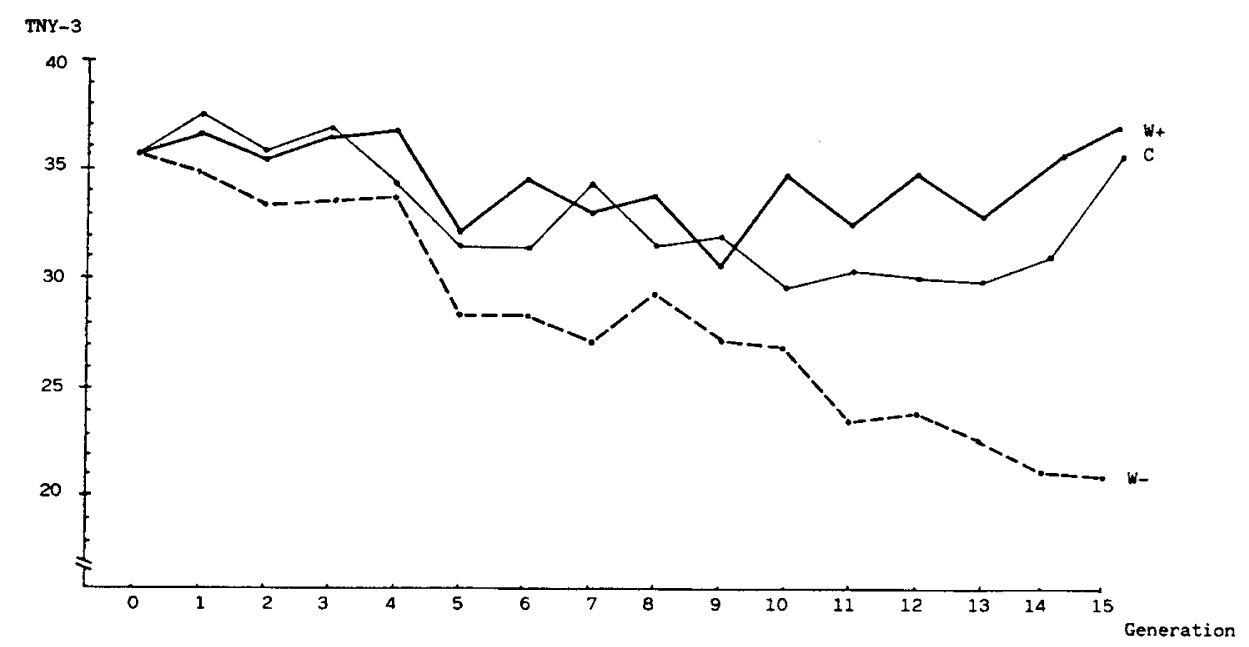

Fig. 5

Means for the total number of young born in the first 3 births (TNY-3) in $W^{+}, W^{-}$and $C$ line.

Correlated response in TNY-3 followed rather closely that of 1st litter size. Little change was detected in the $\mathrm{W}^{+}$line for TNY-3 whereas a large decline was found in $\mathrm{W}^{-}$. Nevertheless changes in $\mathrm{W}^{+}$for TNY-3 were statistically significant $(\mathrm{P}<0.05)$.

Realized genetic correlation calculated between 6-week body weight and the 1st litter size was not high $(0.21 \pm 0.07)$, the values obtained for the 2 nd and 3 rd litter size and TNY-3 reaching a similar level (table 4). The values obtained for $\mathrm{W}^{+}$and $\mathrm{W}^{-}$ separately showed a pronounced asymmetry. Realized genetic correlation between 6week weight and the 1st litter size was $0.03 \pm 0.07$ in $\mathrm{W}^{+}$(not significantly different from zero) and $0.42 \pm 0.06$ in $\mathrm{W}^{-}$, the corresponding values between 6-week weight and TNY-3 being $0.15 \pm 0.04$ in $\mathrm{W}^{+}$and $0.43 \pm 0.04$ in $\mathrm{W}^{-}$.

The percentage of fertile matings maintained a similar level (with some fluctuations) through generations $1-13$ (figure 6). The average value per generation was 88.4 p. 100 in $\mathrm{W}^{+}$and 88.4 p. 100 in $\mathrm{W}^{-}$. However line $\mathrm{W}^{+}$showed a sharp decrease in generations 14 and 15, whereas no change was observed in the low line. The percentage of fertile matings measured in generation 15 was 60 p. 100 in $\mathrm{W}^{+}$and 88 p. 100 in $\mathbf{W}^{-}$. 
TABLE 4

Realized genetic correlations between 6-week body weight and other traits.

\begin{tabular}{|c|c|}
\hline Traits & $\mathrm{r}_{\mathrm{Gr}} \pm$ S.E. \\
\hline 3-week body weight & $0.96 \pm 0.03$ \\
\hline 3-6 week gain ... & $0.50 \pm 0.07$ \\
\hline 1st litter size $\ldots \ldots \ldots$ & $0.21 \pm 0.07$ \\
\hline 2nd litter size $\ldots \ldots \ldots$ & $0.17 \pm 0.10$ \\
\hline 3rd litter size $\ldots \ldots \ldots \ldots \ldots \ldots \ldots \ldots$ & $0.17 \pm 0.10$ \\
\hline TNY$^{-3}{ }^{*} \ldots \ldots \ldots \ldots \ldots \ldots \ldots \ldots$ & $0.29 \pm 0.04$ \\
\hline
\end{tabular}

* TNY-3 : total number of young born in the first 3 births.

* Fertile matings

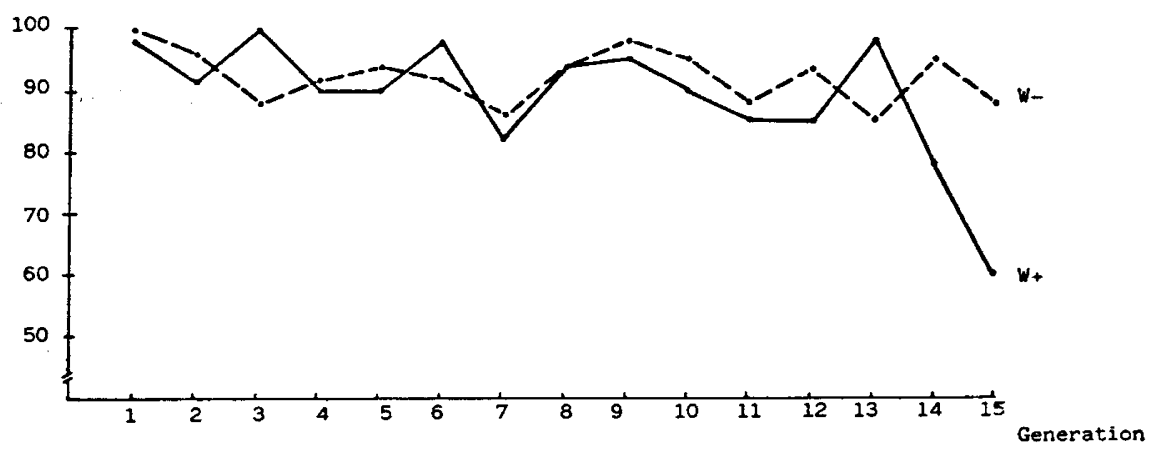

FIG. 6

Percentage of fertile matings in $W^{+}$and $W^{-}$line.

\section{Discussion}

\section{A. Selection differential}

Realized selection differential in $\mathrm{W}^{+}$was higher than that of $\mathrm{W}^{-}$, in agreement with the results obtained generally following divergent selection for body weight (FALCONER, 1953, 1973 ; Legates, 1969).

That effect was mostly due to differences in viability of young born and litter size between the $\mathrm{W}^{+}$and $\mathrm{W}^{-}$lines. Those differences caused the SDe to be larger in the high line than in the low line. Moreover SDr was lower than SDe in $\mathrm{W}^{-}$, while no differences appeared in $\mathrm{W}^{+}$. The decreased litter size of the smaller mice resulted in differences among the females selected in $\mathrm{W}^{-}$with regard to their contribution to the SDr. 
That effect was not important during the 1st period (generations 1-8) because of the standardization of litter size. Thereafter mean litter size was considerably reduced in $\mathrm{W}^{-}$and a large number of families had fewer than 8 mice per litter.

On the contrary, standardization of litters allowed an equal contribution to the following generation for all females selected in $\mathrm{W}^{+}$.

A reduction in the percentage of fertile matings in the low line compared with the high line has been described in some cases (Legates, 1969 ; FALCONER, 1973) contributing to the difference in selection differentials. However, the percentage of fertile matings was similar in $\mathrm{W}^{+}$and $\mathrm{W}^{-}$. Only in generations 14 and 15 was a clear difference detected between the lines, the percentage of fertile matings being lower in $\mathrm{W}^{+}$than in $\mathrm{W}^{-}$.

\section{B. Direct response}

Direct response to individual selection for 6-week body weight in the $\mathrm{W}^{+}$and $\mathrm{W}^{-}$ lines was high, in agreement with the general finding that much of the variation in body weight has an additive genetic base.

Realized heritability estimated for the divergence in generations $1-8(0.28 \pm 0.01)$ did not significantly differ from that calculated in generations $9-15(0.30 \pm 0.01)$. These values may be considered in agreement with those found in several selection experiments for high and low body weight (FALCONER, 1953, 1973 ; LEGATES, 1969 ; ButLer et al., 1984).

Magnitude of response maintained the same level through all the experiment, and no decline was detected in the later generations. The difference between the $\mathrm{W}^{+}$and $\mathrm{W}^{-}$lines after 15 generations of selection amounted to $59 \mathrm{p} .100$ of the base population weight, that value being comparable to that found by FALCONER (1953) after 11 generations of selection $(50$ p. 100).

FalCONER (1953) and Legates (1969) found a higher response in the downward selection, compared with upward selection caused by the asymmetric change obtained in weaning weight. On the contrary results of FALCONER (1973) and BUTLER et al. (1984) did not show significant differences between directions of selection.

Response in $\mathrm{W}^{+}(10.63 \mathrm{~g})$ exceeded somewhat that of $\mathrm{W}^{-}(9.23 \mathrm{~g})$, in contrast with the results obtained in generations 1-8 (Fuente \& SAN Primirivo, 1985). The higher response obtained in $\mathrm{W}^{+}$compared to $\mathrm{W}^{-}$seems to be caused by the difference in $\mathrm{SDr}$ since the realized heritability in $\mathrm{W}^{-}(0.29 \pm 0.02)$ exceeded that of $\mathrm{W}^{+}(0.27 \pm 0.02)$ although the difference was not significant.

\section{Correlated response}

\section{Growth traits}

Selection for body weight seems to accelerate the normal processes of cellular growth (MCCARTHY, 1980) which explains the change generally detected in body weight at different ages as a result of selection for weight at a fixed age (RuTLEDGE et al., 1973 ; EISEN, 1978). 
Weaning weight (3-week) and 3-6 week gain were modified in the $\mathrm{W}^{+}$and $\mathrm{W}^{-}$lines in agreement with expectations. Realized genetic correlations between 6-week weight and 3-week weight or 3-6 week gain were high and similar to those obtained in comparable experiments (EISEN, 1978; BAKER et al., 1984). However, the value calculated between 3-week and 6-week weight seems to be an overestimate since the correlated response obtained in 3-week weight following selection for 6-week body weight is mostly caused by the maternal effect (EISEN, 1972).

FAlCONER (1953) and Legates (1969) had demonstrated a larger correlated response for 3-week weight in the low line relative to the high line. That effect was explained assuming that weaning weight was mostly determined by the mothering ability which is a component of natural fitness and thus expected to be lowered in both directions of selection. However FALCONER (1973) did not find significant differences between upward and downward selection.

In our experiment, correlated response in 3-week weight was very close for upward and downward selection after 15 generations, in contrast with the results obtained in the first 8 generations, which demonstrated a higher response in $W^{-}$than in $\mathbf{W}^{+}$. However, when that response was measured relative to the increase in selection differential, it was larger in the low line than in the high line $\left(0.12 \mathrm{~g}^{-}\right.$in $\mathrm{W}^{-}$and $0.09 \mathrm{~g}$ in $\mathrm{W}^{+}$).

Besides, the asymmetry may have been partly obscured in our experiment by the decreased survival of smaller mice which possibly resulted in an increase in milk supply to the fewer offspring.

The apparent asymmetric response found in postweaning gain was partially the result of a difference in selection differentials between $\mathrm{W}^{+}$and $\mathrm{W}^{-}$. When that correlated response was estimated per unit of selection differential, correlated responses were nearly equal in $\mathrm{W}^{+}(0.19 \mathrm{~g})$ and $\mathrm{W}^{-}(0.18 \mathrm{~g})$.

\section{Reproduction}

Selection for 6-week body weight resulted in a clear differentiation in 1st litter size between the $\mathrm{W}^{+}$and $\mathrm{W}^{-}$lines, in agreement with the results obtained in several experiments with mice (FAlCONER, 1953 ; Fowler \& EdWARdS, 1960 ; Legates, 1969).

Changes in 1st, 2nd and 3rd litter size were large in the $\mathrm{W}^{-}$line, but small in the $\mathrm{W}^{+}$line. As a result a marked asymmetry was detected in the realized genetic correlation estimated in $\mathrm{W}^{+}$and $\mathrm{W}^{-}$separately. On the other hand, a high correlated response in first litter size was obtained in some selection experiments in which body weight was improved (EISEN et al., 1973 ; EISEN, 1978). The weak increase in litter size detected in $\mathrm{W}^{+}$may have been partially caused by the large average litter size of our base population (11.35, 12.59 and 12.62 mice at 1st, 2nd and 3rd parity, respectively).

The analysis of the components of 1st litter size performed in generation 13 of the present experiment (BAYON et al., 1986) showed a high increase in ovulation rate in $\mathrm{W}^{+}$; nevertheless, a large increase in pre-implantation mortality also occurred which reduced the difference in litter size between the $\mathrm{W}^{+}$and the control line.

A comparable result was obtained by BradFord (1971) and BARRIA \& BRAdFord (1981) in a line selected for 3-6 week gain, in which no correlated response in first litter size was detected because of the high increase in pre-natal mortality. 
Correlated responses in 1st litter size found in our experiment were the result of :

- changes in ovulation rate in the direction of selection;

- an increase in pre-natal loss both for upward and downward selection (BAYON et al., 1986).

As suggested by BRADFORD (1971) it seems that, in contrast to ovulation rate, prenatal mortality is not predictably associated with body weight, which explains the variable correlated response in litter size following selection for weight gain.

Besides, a decrease in fertility is a common observation in selection experiments for increased body weight (BradFord, 1971 ; FraHM \& Brown, 1975 ; Barria \& BRADFORD, 1981). That effect was detected in our experiment in the last generations (14 and 15).

Our results are in fairly good agreement with those of BRADFORD (1971) and BARRIA \& BRADFORD (1981), and indicate that selection for increased body weight did not significantly increase 1st litter size, while fitness was depressed as the result of increased pre-natal loss and decreased fertility.

On the other hand, selection for small body weight led to a decline in litter size (due to a decrease in both ovulation rate and pre-natal survival), while fertility was not modified.

In terms of practical breeding it seems, as indicated by BARRIA \& BRADFORD (1981), that intermediate sizes are more efficient reproductively than extremely large sizes.

Received November 4, 1986.

Accepted March 18, 1987.

\section{References}

Baker R.L., Cox E.H., Carter A.H., 1984. Direct and correlated responses to selection for weaning weight, post-weaning weight gain and six-week weight in mice. Theor. Appl. Genet., 67, $113-122$.

Barria N., Bradford G.E., 1981. Long-term selection for rapid gain in mice. II. Correlated changes in reproduction. J. Anim. Sci., 52, 739-747.

Bayon Y., Fuente F., SAN Primitivo F., 1986. Effects of selecting for litter size and body weight on the components of litter size in mice. Livest. Prod. Sci., 14, 195-203.

BRADFORD G.E., 1971. Growth and reproduction of mice selected for rapid body weight gain. Genetics, 69, 499-512.

Butler I. Von, Willeke H., Pirchner F., 1984. Two-way within-family and mass selection for 8week body weight in different mouse populations. Genet. Res. Camb., 43, 191-200.

EISEN E.J., 1972. Long-term selection response for 12-day litter weight in mice. Genetics, 72, 129 . 142 .

EISEN E.J., 1974. The laboratory mouse as a mammalian model for the genetics of growth. 1st World Congress on Genetics Applied to Livestock Production, Madrid, October 7-11, 1974, 1, 467-492, Editorial Garsi, Madrid.

EISEN E.J., 1978. Single-trait and antagonistic index selection for litter size and body weight in mice. Genetics, 88, 781-811.

Eisen E.J., Hanrahan J.P., Legates J.E., 1973. Effects of population size and selection intensity on correlated responses to selection for post-weaning gain in mice. Genetics, 74, 157-170. 
FALCONER D.S., 1953. Selection for large and small size in mice. J. Genet., 51, 470-501.

FAlconer D.S., 1973. Replicated selection for body weight in mice. Genet. Res., 22, 291-321.

Fowler R.E., Edwards R.G., 1960. The fertility of mice selected for large or small body size. Genet. Res., 1, 393-407.

Frahm R.R., Brown M.A., 1975. Selection for increased pre-weaning and post-weaning weight gain in mice. J. Anim. Sci., 41, 33-42.

Fuente F., San Primrtivo F., 1985. Selection for large and small body weight in mice, and its implications for multiparous species. Z. Tierz. Züchtgsbiol., 102, 221-229.

HiLl W.G., 1971. Design and efficiency of selection experiments for estimating genetic parameters. Biometrics, 27, 293-311.

Legates J.E., 1969. Direct and correlated responses to selection in mice. Genet. Lect., 1, 149-165.

McCarthy J.C., 1980. Morphological and physiological effects of selection for growth in mice. In : Robertson A. (ed.), Selection Experiments in Laboratory and Domestic Animals, 100-109. Commonw. Agric. Bur., Slough.

MCCARTHY J.C., 1982. The laboratory mouse as a model for animal breeding: a review of selection for increased body weight and litter size. 2nd World Congress on Genetics Applied to Livestock Production, Madrid, October 4-8, 1982, 5, 66-83, Editorial Garsi, Madrid.

RUTLEDGE J.J., EisEN E.J., Legates J.E., 1973. An experimental evaluation of genetic correlation. Genetics, 75, 709-726. 